\title{
THE PRESENT METHOD OF TAXING TRUST INCOME: A CRITICISM AND PROPOSED REVISION
}

\author{
HENRY A. FENN $\uparrow$
}

SINCE the inception of the income tax in 1913 the taration of trust income has been an ever-vexing problem. Under the first income tax law a trust was not treated as a separate taxable entity. The Act levied a tax on the net income of all individuals, but merely required fiduciaries to file "a return of the net income of the person for whom they act, subject to this tax, coming into their custody" and to withhold the normal tax. ${ }^{1}$ Because of the lack of a taxable entity against which the tax could be levied, income collected by a trustee and held for the benefit of unborn or unascertained persons escaped the tax."

To remedy this casus omissus the 1916 Act specifically provided that income accumulated in trust for the benefit of unborn or unascertained persons should be taxed, "the tax in each instance, except when the income is returned for the purposes of tax by the beneficiary, to be assessed to the . . . trustee." 3 And by the 1917 Act the fiduciary was required to file a return "of the income of the person, irust, or cstate for whom or which they act." 4 By these Acts the fiduciary was made a "taxable person" and the estate or trust a separate taxable entity. "The final step was taken in 1924 when the fiduciary was made primarily liable for the tax on all income collected by him and allowed deductions for the amounts of income distributed to or properly credited to the beneficiaries during the taxable year. ${ }^{6}$

This treatment of the trust as a separate, taxable entity was thought necessary to assure the taxation of all trust income once. The writer believes that such treatment is not necessary to assure this result: that it is unrealistic; and that in many cases it results in a loss of revenue

$\dagger$ Assistant Dean, School of Law, Yale University.

1. 38 STAT. 168 (1913).

2. Smietanka v. First Trust \& Savings Bank, 257 U. S. 602 (1922).

3. 39 STAT. 756 (1916).

4. 40 Stat. 300 (1917) (Italics supplied).

5. Merchants' Loan \& Trust Co. v. Smietanka, 255 U. S. 509 (1921).

6. 43. Stat. 275 (1924). This act also added provisions designed to prevent avoidance of the graduated surtax brackets by the creation of revocable and other types of trusts in which the grantor retained rights in and control over the trust property or the income therefrom. Such trusts are not within the scope of this paper, however, since if the income of the trust is taxable to the grantor thereof, it is not taxable to cither the trustee or the beneficiaries and the problems discussed herein do not arise. For a recent discussion of the status of such trusts see Pavenstedt, The Broadencd Scope of Scdion: 22(a): The Evolution of the Clifford Doctrine (1941) 51 Y YLE L. J. 213. 
and inequality of tax burdens between taxpayers. The purpose of this article is to point out the more glaring defects in the present method of taxing trust income, and to suggest a form of statute which, it is believed, would remedy these defects and afford a sound basis for the taxation of trust income.

The treatment of the trust as a single entity, taxable as an individual, is unrealistic on its face. Most trusts consist of three distinct classes of persons - the trustee, the income beneficiaries, and the remaindermen. The income beneficiaries and the remaindermen are the persons who receive all the benefits; the trustee, as such, although he has legal title, receives none. It is the purpose of tax laws that the person who receives the benefits of income shall pay the tax and pay it at the rates applicable to him. This purpose is recognized to a limited extent in the case of trust income by the requirement that all income currently distributable or properly paid or credited to the beneficiary during the taxable year must be included in the return of the beneficiary whether he actually receives it or not. ${ }^{7}$ Yet, in the case of all other trust income this purpose is completely ignored and all such income is taxed to the trustee, regardless of who the beneficiary may be or what the rate would be if the beneficiary were taxed. In other words, the one person connected with the trust who receives no benefits from its income is treated as the person to be taxed.

The loss of revenue resulting from this treatment of the trust as a single taxable entity results from the tax-consciousness of grantors and trustees at the time of the creation, and during the administration, of the trust. In the past trusts created without consideration of income tax effects have frequently resulted in additional revenue, but with the increased tax-consciousness now shown by laymen as well as lawyers, it seems unlikely that this result will continue to occur with any frequency. As long as the trust continues to be treated as a single taxable entity, control of the tax effects will remain in the hands of the grantor and trustee, and they will endeavor to minimize the tax liability as far as possible.

Let $u$ s assume that a tax-conscious person contemplates creating a trust. The many opportunities open to him under the law as it now stands are best discussed by example.

$A$ desires to leave his property by will ${ }^{8}$ to his wife and his four children. A trust is the obvious device to reduce estate taxes and $A$ also desires to reduce the taxes which his wife and children would have

7. INT. Rev. Code §162(b) (1939).

8. Testamentary trusts are used throughout this paper for the purpose of illustration in order to avoid any question of the taxation of the trust income to the grantor. The same tax effects result from similar inter vivos trusts if the income is not taxed to the grantor. 
to pay upon the trust income. He estimates that his estate, after the payment of his debts, administration expenses, and taxes, will yield an annual income of approximately $\$ 32,000$, aside from tax exempt income. His wife has taxable income of her own, amounting to about $\$ 32,000$ a year, so that she will have approximately $\$ 64,000$ of taxable income each year after $A$ 's death. The tax liability on this income will depend in large part upon the wording of the trust agreement. To estimate the income tax liability under the present law we start with the following basic assumptions:

1. The trust in question is in existence during the entire year of 1942.

2. The income tax rates remain unchanged during the entire year.

3. During 1942 the trust has a net income from stocks and bonds of $\$ 32,100$, none of which was interest on government obligations or on tax-free government bonds, and no other taxable income or deduction.

4. During 1942 the wife had a surtax net income from stocks of domestic corporations owned by her of $\$ 32,000$.

On these assumptions, we have the following possibilities:

(a) If the trust provides that the income is to be paid to the wife during the year in which it is collected by the trustee, she will have to pay a federal income tax of $\$ 30,051$ on the $\$ 64,100$ of gross income, which she received from her own securities and from the trust.

(b) If, however, the will provides that the trustee is to pay to the wife an annual sum of $\$ 20,000$, which is to be paid out of the income to the extent that it is sufficient, and the balance out of the principal of the trust, then this $\$ 20,000$ will be received by the wife tax-free, and she has to pay an income tax of only $\$ 11,168$ on her own income. Of course, an income tax is paid on the $\$ 20,000$ as a part of the income of the trust, but this tax is paid by the trustee and at lower rates. The tax on the trust income is $\$ 11,800$, so the government receives from the same income of $\$ 64,100$ only $\$ 22,348$, instead of $\$ 30,051$.

Certain disadvantages are involved in this plan, generally referred to as an "annuity" trust. If the income from the trust should increase in the future, the wife would still receive only $\$ 20,000$ a year from the trust. If, on the other hand, the income should decrease to any marked extent, then the principal of the trust might have to be used to pay the $\$ 20,000$ a year to the wife. Should this happen, there might be a substantial reduction in the amount of property which the children would ultimately receive, since this dipping into principal, once begun, would probably continue in increased amounts each year as the source of the trust income was depleted.

(c) If the trustee is directed to pay to the wife on January 3 of each year of her lifetime the net income of the trust collected during

9. Burnet, Comm'r v. Whitehouse, 283 U. S. 148 (1931); Helvering, Comm'r v. Pardee, 290 U. S. 365 (1933). 
the calendar year ending on the preceding December 31 , the wife will then receive, tax-free, "the trust income less the amount of the tax paid by the trustee. The income tax liability is the same as in the previous type of trust. That is, the government receives from the same $\$ 64,100$ of income only $\$ 22,348$ in tax. But this plan assures the wife of all the trust income and protects the trust principal for the children.

However the plan, known as a "Dean" trust," has disadvantages. In the first place, the wife does not get any of the year's income unless she lives until January 3 of the next year. Secondly, the plan may not stand up in the case of a New York resident, since it may be attacked by the government as involving an accumulation of income which is invalid under New York law. And, finally, the Dean case was not taken to the Supreme Court, and hence the plan cannot be said to be as well established law as the annuity trust plan. At present the Commissioncr of Internal Revenue is not contesting the ruling in the Dean case, but he may change his position at any time, and it might then be necessary for the trustee to litigate the question to the Supreme Court. o

(d) If $A$ is willing to accept the risk inherent in the "Dean" plan, he can effect substantial additional savings in income taxes by combining it with the multiple trust set-up. Instead of creating a single "Dean" trust by his will, he may create four of them, one for each of his children, the income from each to be paid to his wife. In this way, the lower income tax brackets may be utilized four times, and the total tax on the $\$ 64,100$ of income reduced to $\$ 15,985$.

The tax result of the above types of trust may be summarized as follows :

The wife would pay $\$ 30,051$ on her combined personal and trust income if she received the latter from a straight income trust. The tax on her own surtax net income of $\$ 32,000$ would be $\$ 11,158$ if she did not have to include the trust income in her returns. Treating the difference between these two amounts - $\$ 18,883$ - as paid entirely out of the trust income, the amount of $\operatorname{tax}$ the government receives upon the $\$ 32,100$ of trust income is:

(a) From the straight trust: . . . . $\$ 18,883$.

(b) From the annuity trust: . . . . $\$ 11,180$.

(c) From the single "Dean" trust: . . . \$11,180.

(d) From the four "Dean" trusts: . . \$4,817.

The "discretionary" trust is another type of trust which may also be used successfully to reduce income taxes on trust income. It is most useful in states in which accumulations of income are not restricted, but it may be used to a limited extent in states like New York which limit accumulations of income to accumulations for the benefit of a minor.

10. Commissioner v. Dean, 102 Fed. (2d) 699 (C. C. A. 10th, 1939). 
By the terms of such a trust, the trustee is given power to distribute or withhold from distribution current income in the exercise of his discretion. For income tax purposes, all income distributed to the beneficiary in the year in which it is collected by the trustee is included in the return of the beneficiary. ${ }^{11}$ The rest of the income is included in the net taxable income of the trust and the tax paid by the trustee. ${ }^{12}$ This latter income may be distributed to the beneficiary in subsequent years free of further income tax. ${ }^{13}$

For example, a common type of trust provides that the income is to be paid to $D$ during his lifetime and upon his death the principal is to be distributed to his children. The trustee is authorized to accumulate so much of the income during $D$ 's minority as is not needed for his support and maintenance, but all accumulations are to be paid to $D$ when he attains twenty-one, or to his estate if he dies. During $1941 \mathrm{D}$ is a minor, unmarried, with no dependents, is supported by his father, has no income other than that from the trust and no deductions. The net income of the trust during 1941 amounted to $\$ 11,000$, all of which is from dividends and fully taxable interest.

If the trust has no net capital gain or loss during the year and the trustee distributes all of the income to $D, D$ will pay a tax thereon of $\$ 1,780.50$. If the trustee accumulates all of the income, the trustee will pay a tax thereon of $\$ 1,981$ - approximately $\$ 200$ more. If, however, the trustee distributes one-half of the income and accumulates the balance, the total tax paid by $D$ and the trustee will be only $\$ 1,234.50-$ $\$ 746.50$ less than if it had all been accumulated.

If, in addition to the ordinary income, the trust during 1941 realized a net capital loss of $\$ 20,000$ on the sale of assets held for more than twenty-four months, very different taxes result. If the trustee distributes all of the income during $1941, D$ will pay the same tax as before$\$ 1,780.50$; but if the trustee accumulates the entire $\$ 11,000$, the total tax payable thereon would be only $\$ 90$, because of the allowance of the capital loss as an offset against the ordinary income.

Thus the trustee, by a judicious application of his discretion to distribute or withhold income and by picking the year in which to realize any losses which the trust may have on its books, can reduce, even in the case of a reasonably small trust, the tax payable on trust income from $\$ 1,981$ to $\$ 90$.

If the beneficiary has substantial property of his own, a tax-conscious trustee under such a discretionary trust can control the tax liability to an even greater extent. He can confer with the beneficiary prior to the end of the taxable year to ascertain the most advantageous division of

11. INT. Rev. CODE $\$ 162$ (c) (1939).

12. Id. $\$ 161(\mathrm{a})(4)(1939)$.

13. U. S. TREAS. Reg. 103, Art. 19.162-1(3). 
the trust income for income tax purposes - the general purpose being to divide the total taxable income of the beneficiary and the trust into approximately equal parts in order to utilize the lower surtax brackets twice.

Properly administered, this is a most effective method of tax reduction. If the beneficiary has an income larger than that of the trust, the trustee will withhold distribution of the trust income until after the end of the year. If the beneficiary has a smaller income than the trust, the trustee will distribute enough of the trust income to equalize the amount of income taxable to the beneficiary and the amount taxable to the trustee. If the trust has capital gains, a larger part of its income will be distributed; if it has capital losses which can be used to reduce the net taxable income, a larger part of the income will be withheld until after the close of the taxable year and then distributed to the beneficiary. If the beneficiary has capital losses or other deductions in excess of his income, a sufficient amount of trust income will be distributed during the taxable year to permit the beneficiary to utilize such losses and deductions to best advantage for income tax purposes.

To summarize: The concept of the trust as a single taxable entity for income tax purposes has a deleterious effect upon the revenue, because it lodges in the hands of tax-conscious grantors (at the time of the creation of the trust) and tax-conscious trustees (during the administration of the trust) many means of escaping high surtaxes on trust income.

The present method of taxing trust income also gives rise to many inequalities of tax burden, both as between individuals who are trust beneficiaries and those who are not, and as between individuals who are beneficiaries of different trusts. Yet achievement of at least approximate equality of tax burden between all taxpayers, becomes increasingly important in the light of present high tax rates, and the prospect of even higher rates.

The inequalities here discussed are due in part to the treatment of the trust as a single entity, rather than as a group of entities with separate beneficial interests in the trust; they also stem from a failure to recognize the trust device as sui generis, and from attempts to apply to trusts, with certain minor exceptions, the provisions of tax laws devised for the taxation of individuals.

It should be noted that none of the inequalities occur in straight income trusts where the tax law recognizes the separate beneficial interests of the income beneficiary and the remaindermen. ${ }^{14}$ For example, in most trusts the interests of the income beneficiaries and the remaindermen are treated as separate and distinct under trust law, and income may not

14. One possible exception may occur in connection with the deduction of incomc commissions as an aftermath of the decision in City Bank Farmers' Trust Company $v$. Helvering, 313 U. S. 121 (1941). See, infra, p. 1151. 
be used to augment principal nor may principal be distributed to the income beneficiary in the absence of express provisions in the trust instrument. Thus, gains realized on the sale or other disposition of principal assets constitute principal and may not be paid to the income beneficiary. Conversely, losses realized on the sale of trust assets must be borne by the remaindermen and may not be recouped from the income of the trust. In the case of a straight income trust, the tax law recognizes these principles of trust law by taxing the income to the beneficiary and the capital gains to the trust and by refusing to permit the income beneficiary to reduce his net taxable income from the trust by a deduction of capital losses sustained by the trust. ${ }^{15}$ Thus there is no inequality of tax burden between an individual who derives all of his income from his own property and an individual who derives the same amount of income in part or entirely from a straight income trust. If the first individual has a surtax net income of $\$ 64,100$, he pays an income tar of $\$ 30,051$. If the second individual has a surtax net income from his own property of $\$ 32,000$ and in addition receives $\$ 32,100$ from the trust, he pays the same amount of tax.

But contrast this tax situation with that existing where the "Dean" trust device is adopted. Consider an individual who has a surtax net income of $\$ 32,000$ and is also the beneficiary of a four-share Dean trust which has a net income of $\$ 32,100$. His $\$ 64,100$ total income is burdened with a tax of only $\$ 15,985$ - more than $\$ 14,000$ less than that of the other two individuals.

Such inequality of tax burden is justified in legal theory by the statement that the beneficiary of the Dean trust may never receive any of the year's income from the trust since he has to live for three days after the close of the calendar year in order to be entitled to it, whereas, if the other individuals die, they have received or are entitled to receive, through their estates, all income collected and accrued to the time of death. Therefore, says the Law, since he may never receive the income, he cannot be taxed upon it - to do so would be inequitable, or, in legal parlance, would be taking his property without due process of law.

But the only event which can prevent his receiving the income is his death prior to the appointed date, and this is an event which, literally, can happen only once in a lifetime. To permit, during every year of the trust except the last, an inequality of tax burden so patent, in order to prevent an inequity in that one year, does not appeal to this writer's conception of equality or equity.

Conceding, however, that it would be inequitable to tax the beneficiary on income which he may never receive, is there any reason why the income should not be taxed at the rates at which it would have been

15. Abell v. Tait, 30 F. (2d) 54 (C. C. A. 4th, 1929), cert. denicd, 279 U. S. 849 (1929). 
taxed had he received it? Or, to put it another way, is there any reason why the law should blind itself to realities and tax the income at rates applicable to a person without other income, rather than accept the fact that the beneficiary is in all probability going to receive the benefits of the income, determine the tax rate on the income in the light of such probability, and make a provision for a refund of any excess tax paid, if the probability does not occur? Included in the statutory scheme hereinafter suggested are provisions designed to accomplish this result.

Another inequality between taxpayers occasioned by the treatment of the trust as a single entity rather than as a group of entities with separate beneficial interests, is illustrated by the following situations: $A$ and $B$ are father and son, both of full age and with sizable estates. During $1941 A$ has a surtax net income of $\$ 32,000$ on which he will pay a tax of $\$ 11,168$. $B$ during the same year suffered business reverses, was forced to liquidate large holdings of securities at a heavy loss, and for income tax purposes has long-term capital losses on securities held for more than twenty-four months aggregating $\$ 64,000$ in excess of all his net income. If $A$ were to claim that he was entitled to use $B$ 's excess losses to offset his net income, he would be told that he had suffered no loss and was not entitled to the deduction.

$C$ and $D$ are father and son who have no income or property other than their interest in a single "Dean" trust of which $C$ is the income beneficiary and $D$ the remainderman. During 1941 the trust has a net income of $\$ 32,100$ which is fully taxable. During the same year the trustee realized a net long-term capital loss on the sale of assets held for more than twenty-four months of $\$ 64,000$. This loss is borne by the principal belonging to $D$, so that $C$ has suffered no more loss than $A$, but here, because the trust is treated as a single entity, the loss is allowed as an offset against $C$ 's income from the trust. Thus $C$ 's tax burclen will amount to only $\$ 1,580$.

The converse situation may occur where the "Dean" trust has net capital gains - that is, both $C$ and $D$ may be burdened with a higher tax because of the lumping for tax purposes of the capital gains with the ordinary income. In such case the revenue is increased as a result of treating the trust as a single tax entity. Increases thus obtained may more than make up the decreases resulting from the allowance of capital losses as an offset to ordinary income. ${ }^{16}$ But even if this is the case, it merely emphasizes the deficiencies of a tax system which leaves the allocation of the tax burden to chance; and which permits unequal allocations of

16. Statistics of INCOME FOR 1938, Part I, shows that fiduciary returns indited $\$ 26,289,000$ net short-term capital gains and $\$ 83,569,000$ net long-term capital gains as against $\$ 64,548,000$ net long-term capital losses, but the actual effect on the revente is inconclusive in view of the lack of information as to the rates applicable to the capital gains and to the income offset by the capital losses. 
the burden between trust beneficiaries and other taxpayers and between beneficiaries of different types of trusts.

Further inequalities in taxation result from a failure to recognize the trust device as sui generis, and from the application to it, with certain minor adjustments, of the provisions governing the taxation of individuals. The extreme rationales which courts are forced to adopt in order to accommodate tax laws to the realities of the trust device are illustrated by City Bank Farmers' Trust Co. z'. Helciring. ${ }^{17}$ The will creating the trusts in question provided that the income of each should be paid to a son of the testator during his lifetime and after his death to his lineal descendants as long as the trust should continue; upon the termination of the trust (which could not occur prior to the death of the son) the principal was to be distributed to the lineal descendants of the son then living. The trustees were given authority to accumulate in their discretion all or any part of the trust income during the minority of the son; upon the son's attaining twenty-one all accumulations were to be paid to him; if he died before attaining twenty-one, such accumulations were to become a part of his estate.

During the taxable year in question most of the trust income was accumulated. After filing the return for the trust, the trustees sought to obtain an additional deduction for the amount of principal commissions paid during the taxable year out of the principal of the trust pursuant to a decree of the Surrogate's Court. The Supreme Court held that the deduction was not allowable, because the trust was not "carrying on a . . . business" within the meaning of the Internal Revenue Code.

The Court was compelled to adopt this esoteric reasoning in order to deny the deduction; for the law provides that the net income of a trust "shall be computed in the same manner and on the same basis as in the case of an individual, except that" 18 a different charitable deduction is allowed and a deduction is allowed for all income which the beneficiary is required to include in his return. No other express provision regarding trust deductions is made and therefore recourse must be had to Section 23 of the Code which sets forth in some detail the deductions to which an individual is entitled. Among these deductions are "all ordinary and necessary expenses paid or incurred during the taxable year in carrying on any trade or business." 19

Under these statutory provisions the City Bank Farncrs' Trust Co. case was presented to the Supreme Court. The Government contended that the case was controlled by the Court's decision in Higgins a. Commissioner, ${ }^{20}$ decided a few months before, in which it had been held that

17. 313 U. S. 121 (1941).

18. INT. Rev. CODE \$ 162 (1939).

19. Id. $\$ 23(\mathrm{a})(1939)$.

20. 312 U. S. 212 (1941). 
an individual was not entitled to deduct as business expenses the cost of maintaining an office or the salaries of the office force when these expenses related merely to keeping records, collecting interest and dividends. from securities, and exercising managerial attention for investments. The trustees contended that the Higgins case was distinguishable and that a trustee must be considered as carrying on a business within the meaning of the Code. As previously noted, the Court agreed with the Government.

It is unimportant, for the purposes of this discussion, whether or not the decision is sound. Its desirability from the point of view of equality of tax burden between income beneficiaries of trusts and other taxpayers is clear. Some less desirable consequences of the decision will be noted shortly. The point to be emphasized here is that the Supreme Court should never have had to decide whether or not the trust was "carrying on a . . . business" within the meaning of the Code. No one called upon to decide, de novo, what expenses should be allowed a trust as deductions in computing its net income would ever define them as "expenses paicl or incurred during the taxable year in carrying on a trade or business". Even a cursory consideration of the problem would have disclosed that no expenses of a trust are "personal" in the sense in which that word is used in Section 24 of the Code as contrasted with business expenses; that the principal expenses of most trusts are trustees' commissions and attorneys' fees, which are authorized by law and subject to approval by the court having jurisdiction of the trust; and that words which may be appropriate to describe the many varied expenses which it is deemed advisable to allow individuals to deduct are utterly meaningless when applied to expenses of a trust.

If this confusion in the taxation of trusts is to be avoided, trusts should no longer be treated as individuals and the statute should specifically provide for the deductions to be allowed to trusts. Inasmuch as expenses of trusts are much more limited in character than those of individuals, it would seem possible to be reasonably explicit in these provisions, but at the very least, descriptive words could be used which have an accepted meaning with reference to trust expenses.

Certain new inequalities of tax burden appear to be arising as an aftermath of the City Bank Farmers' Trust Co. case. In terms of dollars and cents, these inequalities are of little importance, but the fact that they arise out of a decision which eliminated one type of inequality exemplifies the difficulties which are encountered when statutory provisions directed at the taxation of individuals are applied to trusts.

Prior to the City Bank Farmers' Trust Company decision it was accepted practice, so far as the writer has been able to determine, to allow, in computing the net income of the trust, a deduction for trustees' in- 
come commissions and other ordinary expenses of administration which under trust law are payable out of the income of the trust. ${ }^{21}$ Since that decision the Treasury Department is taking the position that such deductions may not be allowed.22

Whether or not such deductions should be allowed is of secondary importance $;^{23}$ the important thing is that as long as the trust is treated as an individual under the law, their allowance or disallowance cannot be decided on the merits. The decision must be made in terms of whether or not the trust is "carrying on a trade or business" within the meaning of Section 23 of the Code. And if it is held that the trust is carrying on a business, ${ }^{24}$ then not only expenses paid from income, but also expenses paid from principal, must be allowed as deductions!

To summarize again: To safeguard tax revenues, and to equalize the tax burden among taxpayers, the trust should not be treated as a single taxable entity or taxed under statutory provisions promulgated to cover the taxation of individuals. The law should recognize that a trust is composed of a group of beneficial interests, separate as between income and principal; that these interests are property belonging to persons who are or may be made subject to the income tax statute as individuals or as classes of trust beneficiaries. The law should also abandon the application to trusts of rules dealing with deductions allowed to individuals and substitute express provisions covering trust deductions. It is apparent that these desirable results can only be achieved by a complete revision of the statutory scheme for taxation of trust income.

21. See G. C. M. 22799, 3 C. C. H. 1941 Fed. Tas Serv. ๆ 6450, and carlier Treasury rulings therein mentioned.

22. Special Ruling, dated Sept. 18, 1941, 3 C. C. H. 1941 Fed. Tax Scrv., I6529, providing in part: "Inasmuch as sums paid in connection with the management, protection and conservation of trust property are not currently distributable to trust beneficiaries and are not otherwise deductible by the trust, they must be included in the gross income of the trust. In other ziords, the gress income of the trust may nol be reduccd by the amount of such expenditures in deternining the net tasalle inceme of the irust" (Italics supplied).

23. Appealing arguments can be made on both sides. To allow them will germit that amount of trust income to go free of tax. To refuse to allow them will burden the beneficiary with a tax on income which he can never receive, for even though the trustee pays the tax, it will be paid out of income which would otherwise be distributable to the beneficiary.

24. In Higgins v. Commissioner, 312 U. S. 212 (1941), the Cummissioner coneeded that the management of improved real estate and the collection of rents therefrom constituted carrying on a business within the meaning of seetion 23 of the Code; in the same case the Supreme Court emphasized that no general rule could be laid down, but that the decision must be based upon the circumstances of each case. 


\section{A Proposed Statute for the Taxation of Trust Incone}

Gross income of trusts would be defined by reference to Section 22 (a) of the Code, but the statute should provide what deductions and credits are to be allowed to trust in lieu of the deductions and credits allowed to individuals. In the trust return the trustee would be required to allocate the gross income of the trust and the deductions and credits allowed therefrom among each of four tax classes of income, hercinafter defined, and to include the names and addresses or other description of the persons or classes of persons beneficially interested in each class of income. From this point on the structure of the suggested plan is set forth in the form of a statute.

Tax classes of trust income. - Trust income shall be divided into the following classes for the purpose of this supplement:

(a) Income currently distributable.

(b) Income which forms a part of the principal of the trust.

(c) Income accumulated in trust for the benefit of unborn or unascertained persons.

(d) Income accumulated in trust for the benefit of a presumptive beneficiary.

Definitions of tax classes of trust income.

(a) Income currently distributable. - The following income shall be considered income currently distributable:

1. Income which the beneficiary has the right to receive during the taxable year, whether distributed to the beneficiary or not;

2. Income which, under the terms of the instrument creating the trust, may, in the discretion of the trustee, ${ }^{20}$ be either distributed to a beneficiary or accumulated, to the extent that such income is properly paid or credited to a beneficiary during the taxable year;

3. Income which, under the terms of the instrument creating the trust, is to be used or may be used to satisfy an annuity or other periodic payments of a fixed amount; and the annuitant or other payee shall be considered the beneficiary thereof.

For the purpose of this section every distribution made to a beneficiary during the taxable year of the trust is deemed to have been made out of the income received by the trustee during such taxable year to the extent of such income without regard to the amount of income received by the trustee prior to the time any such distribution is made.

25. The administrative feasibility and the net effect on tax revenues of this or any other plan can only be determined by Treasury officials with access to the source material contained in the fiduciary returns filed in previous years.

26. This phrase should be defined as meaning, throughout the statute, "in the discretion of the trustee or any other person vested with such discretion." 
(b) Income which forms a part of the principal of the trust. - The following income shall be considered income which forms a part of the principal of the trust:

1. Income which, under the terms of the instrument creating the trust or, in the absence of any applicable provision in the instrument, under the laws governing the administration of the trust, constitutes principal of the trust for trust accounting purposes and which, under such instrument or such laws, may only be distributed by the trustee as principal of the trust;

2. Income which, under the terms of the instrument creating the trust or, in the absence of any applicable provision in the instrument, under the laws governing the administration of the trust, is properly commingled with or considered as a part of the principal of the trust and which, under such instrument or such laws, may only be distributed by the trustee to the same person or persons, at the same time or times, and in the same proportion as the principal of the trust is to be distributed.

3. Income which, under the terms of the instrument creating the trust, may, in the discretion of the trustee, be either distributed to a beneficiary or accumulated, and which is not properly paid or credited to a beneficiary during the taxable year of the trust, and which, under the terms of the instrument creating the trust, may not be distributed after the end of such taxable year except to the same person or persons, at the same time or times, and in the same proportion as the principal of the trust is to be distributed.

(c) Income accumulated in trust for the benefit of ninborn or unascertained persons. - Any income

1. accumulated in trust or held for future distribution, and

2. which, under the terms of the instrument creating the trust, may, in the discretion of the trustee, be either distributed to a beneficiary or accumulated, and which is not properly paid or credited to a beneficiary during the taxable year of the trust, and which, under the terms of the instrument creating the trust, may not be distributed after the end of such taxable year in the discretion of the trustee,

which is not considered income which forms a part of the principal of the trust under subdivision (b) hereof, shall be considered income accumulated in trust for the benefit of unborn or unascertained persons, if, but only if, the event upon which the distribution of such income depends, under the terms of the instrument creating the trust, is the death of an ascertained person, and upon the death of such person the income is to be distributed to a child or children or other descendants 
of such person, if any shall then be living, and no child or other descendant of such person is living at the end of the taxable year of the trust.

(d) Income accumulated in trust for the benefit of a presumplize beneficiary. - All income not income currently distributable, or income which forms a part of the principal of the trust, or income accumulated in trust for the benefit of unborn or unascertained persons shall be considered income accumulated in trust for the benefit of a presumptive beneficiary; and the person who would have been entitled to receive such income, if the event upon which its distribution depends had occurred just prior to the end of the taxable year of the trust, shall be considered the presumptive beneficiary thereof; provided, in the case of income which, under the terms of the instrument creating the trust, may, in the discretion of the trustee, be either distributed to a beneficiary or accumulated, and which is not properly paid or credited to a beneficiary during the taxable year, but which may, under the terms of such instritment, be distributed by the trustee, in his discretion, after the end of the taxable year to more than one person, that each such person to whom any part of such income may be so distributed shall be considered the presumptive beneficiary of all of such income to the extent that such income may be distributed to him under the terms of the instrument creating the trust.

\section{Taxation of tax classes of trust income.}

(a) Taxation of income currently distributable. - Income currently distributable shall be included in computing the net income of the beneficiary thereof and the tax thereon shall be paid by such beneficiary.

(b) Taxation of income which forms a part of the principal of the trust. - Income which forms a part of the principal of the trust shall be included in a return filed by the trustee as representative of the remaindermen of the trust and the tax thereon shall be computed at the rates applicable to an individual and shall be paid by the trustee out of the principal of the trust; provided that, in case the trustee is also a trustee of other trusts under the terms of which the principal thereof can only be distributed to the same person or persons and in the same proportions as under the terms of the trust in question, then the trustee as representative of such remaindermen shall file only one return which shall include all income which forms a part of the principal of all such trusts and the tax thereon shall be computed at the rates applicable to an individual and shall be paid by the trustee out of the principal of all of such trusts, the share of such tax applicable to each trust to be determined by multiplying the tax by a fraction the numerator of which shall be the amount of income of that trust included in the 
return and the denominator of which shall be the total amount of income of all the trusts included in the return.

(c) Taxation of incone accumulated in trust for the benefit of unborn or unascertained persons. - Income accumulated in trust for the benefit of unborn or unascertained persons shall be included in a return filed by the trustee as representative of such unborn or unascertained persons and the tax thereon shall be computed at the rates applicable to an individual and shall be paid by the trustee out of the income so accumulated; provided that, in case the trustee is also a trustee of other trusts in which income is accumulated in trust for the benefit of the same unborn or unascertained persons, then the trustee as representative of such unborn or unascertained persons shall file only one return which shall include all income accumulated in trust for the benefit of such unborn or unascertained persons in all trusts of which he is trustee and the tax thereon shall be computed at the rates applicable to an individual and shall be paid by the trustee out of the income of all such trusts, the share of such tax applicable to each trust to be determined by multiplying the tax by a fraction the numerator of which shall be the amount of income of that trust included in the return and the denominator of which shall be the total amount of income of all trusts included in the return.

(d) Taxation of income accumulated in trust for the benefit of a presumptive beneficiary. - Income accumulated in trust for the benefit of a presumptive beneficiary (hereinafter sometimes referred to as "presumptive income") shall be included in a separate schedule $e^{27}$ of the return of the presumptive beneficiary and the tax thereon (hereinafter sometimes referred to as the "net presumptive tax") shall be computed, assessed, and paid as hereinafter provided.

1. Computation of net presumptive tax. - The net presumptive tax shall be computed in the following manner:

$a$. To the total presumptive income add the net income of the presumptive beneficiary as computed in the return to obtain the gross presumptive income.

b. Apply the rates applicable to an individual to the gross presumptive income to obtain the gross presumptive tax.

c. Deduct from the gross presumptive tax the tax on the net income of the presumptive beneficiary as computed in the return to obtain the net presumptive tax.

27. The schedule should require a segregation from other presumptive income of presumptive income which is accumulated in the discretion of the trustee and which may bs distributed by the fiduciary in his discretion after the end of the tasable year to more than one person. 
2. Assessment and payment of net presumptive tax. - The net presumptive tax shall be assessed and paid as follows:

$a$. The Collector with whom is filed a return containing presumptive income (other than presumptive income accumulated in the discretion of the trustee which may be distributed by the trustee in his discretion after the end of the taxable year to more than one person) shall send a notice of assessment to the trustee of such presumptive income assessing the amount ${ }^{28}$ of the net presumptive tax applicable to such income and the tax shall thereupon be due and shall be paid ${ }^{20}$ by the trustee out of such income.

$b$. The Collector with whom is filed a return containing presumptive income accumulated in the discretion of the trustee, which may be distributed by the trustee in his discretion after the end of the taxable year to more than one person, shall forward such return to a central office to be designated by the Commissioner of Internal Revenue. Such central office shall select the return which discloses the largest presumptive tax applicable to such income and shall remit such return to the Collector from whom it was received with a notation that the tax on such income is to be assessed upon the basis of that return, and the Collector shall thereupon proceed to collect the tax upon the presumptive income contained in such return as in the case of other presumptive income.

The central office shall also deduct such presumptive income from the presumptive income set forth in all other returns containing such presumptive income, shall recompute the net presumptive tax on any other presumptive income included in any such return, and shall remit each such return, with an appropriate notation, to the Collector from whom it was received, and the Collector shall thereupon proceed to collect the tax upon any other presumptive income included in the return as in the case of other presumptive income.

c. In case a return contains presumptive income from two or more trusts, the portion of the net presumptive tax applicable to the income of each trust shall be determined by the Collector by multiplying such tax by a fraction, the numerator of which shall be the amount of presumptive income of that trust included in the return and the denominator of which shall be the total amount of presumptive income of all trusts included in the return.

28. The amount of the assessment would be tentative and subject to adjustment upon the audit of the returns of the presumptive beneficiary and the trustee of each trust involved. Consideration should also be given to the liability of the trustee for interest where the audit of the beneficiary's return discloses a deficiency tax, and vice versa.

29. The statute should provide that the trustee is under no duty to verify the correctness of the assessment and shall be fully protected in making payment pursuant to the notice without further inquiry. 
Right to refund for excess tax paid on income accumulated in trust for the benefit of a presumptive bencficiary. - Within two years after the distribution of any income taxed as provided in the case of income accumulated in trust for the benefit of a presumptive beneficiary, the person to whom such income is distributed shall be entitled to file a claim for the refund of the amount ${ }^{30}$ by which any tax paid on such income exceeds the amount of tax which would have been payable upon such income had such income been included in the gross presumptive income of such person for the taxable year in which it was accumulated in trust; provided that, such person shall not be entitled to file a claim for the refund of any tax paid on any income accumulated prior to the beginning of the taxable year in which such person was born.

30. The statute should specify the interest to be allowed on the amount refunded. It is suggested that interest be allowed at a rate not in excess of the rate of interest on long-term Government obligations issued in the year in which the income was accumulated. 